\title{
HUBUNGAN PENDIDIKAN KEDISIPLINAN DAN RELIGIOSITAS DENGAN PERILAKU AGRESIF SISWA
}

\author{
Muhammad Aziz Husnarrijal
}

SMP IBS AI- Islah Bobos

azizhr23@gmail.com

DOI : $10.24235 /$ oasis.v5i2.4985

Received

2019-08-18
Revised

2019-08-20
Approved

2019-09-04

\begin{abstract}
The aggressive behavior of students in school becomes an issue that needs solution to overcome this. Several institutions implement discipline through religious activities that are hoped to increase student religiosity and lead to solving the problem of student aggressiveness. The purpose of this study is to determine the effect of the application of discipline and student religiosity on students' aggressive behavior in the Al-Ishlah Educational Environment for the 2018/2019 Academic Year. This type of research is quantitative with the research method. The results of this study indicate the influence of the implementation of discipline throughout series religious activities and student religious on students' aggressive behavior.
\end{abstract}

Keywords:discipline, religiosity, aggressive behavior.

\begin{abstract}
Abstrak
Perilaku agresif siswa di sekolah menjadi persoalan yang penanganan bersama untuk mengatasi hal tersebut. Beberapa lembaga menerapkan kedisplinan melalui kegiatan keagamaan yang diharapakan dapat meningkatkan religiousitas siswa dan mengarah pada penyelesaian persoalan agresifitas siswa. Tujuan penelitian ini untuk mengetahui pengaruh penerapan pendidikan kedisplinan siswa dan religiositas siswa terhadap perilaku agresif siswa di Lingkungan Pendidikan Al-Ishlah Tahun Pelajaran 2018/2019. Jenis penelitian adalah kuantitatif dengan metode penelitian yang digunakan metode survei. Hasil dari penelitian ini menunjukkan adanya pengaruh penerapan pendidikan kedisiplinan melalui serangkain kegiatan keagamaan dan religiositas siswa terhadap perilaku agresif siswa.
\end{abstract}

Kata kunci: kedisiplinan, religiositas, perilaku agresif. 


\section{Pendahuluan}

Lingkungan memiliki pengaruh besar terhadap perkembangan karakter seseorang. Untuk melahirkan seorang anak yang baik, lingkungan harus diperbaiki terlebih dahulu agar lingkungan menjadi kondusif dari perilaku-perilaku yang menyimpang (Ramdhani, 2014). Ini menunjukkan peran penting lingkungan dalam membentuk dan mengarahkan perilaku seseorang pada masa tumbuh kembang.

Perilaku agresif adalah respon manusia atas lingkungannya. Secara umum, perilaku agresif dapat terjadi dalam bentuk tindakan fisik maupun verbal. Contoh perilaku agresif di lingkungan sekolah adalah berkata-kata kotor dan kurang sopan, berkelahi, menjahili/mengganggu siswa lain, membuat keributan, mengancam, merusak, melanggar peraturan, dan lain sebagainya. Tindakan tersebut dapat memengaruhi yang lain untuk bersikap sama. Oleh karena itu, perilaku agresif perlu mendapatkan tindakan yang cepat agar tidak menjadi wabah atau virus yang berkembang di lingkungan (Yahya \& Megalia, 2016).

Perilaku menyimpang atau perilaku agresif yang bersifat negatif akan merugikan dan berbahaya jika dibiarkan begitu saja berkembang di lingkungan masyarakat. Hal ini tentunya dapat memengaruhi generasi penerus bangsa dan negara (Satria, Nurdin, \& Bachtiar, 2015). Pihak sekolah khususnya guru bimbingan konseling, perlu melakukan upaya berkelanjutan untuk mengatasi hal tersebut. Salah satunya dengan menerapkan kedisiplinan dan memastikan setiap anak melaksanakannya. Pendidikan kedisiplinan adalah salah satu bidang pendidikan karakter yang dapat diterapkan kepada para siswa untuk mengurangi tingkat agresivitas siswa (Hadianti, 2017).

Pendidikan karakter di lingkungan sekolah dengan menerapkan kedisplinan bagi para siswa, ditujukan untuk membangun karakter para siswa. Selain kedisplinan, siswa juga dibutuhkan pendidikan moral yang tepat melalui pemberian pendidikan agama. Pembangunan karakter, moral, religiousitas anak dapat dilakukan dengan cara pembiasaan dan kedisplinan mengikuti kegiatan-kegiatan keagamaan. Hal tersebut diharapkan dapat meningkatkan religiousitas seseorang karena meningkatkan interaksi siswa dengan Tuhan, sesama manusia, dan alam semesta yang disertai keterikatan dan ketaatan manusia terhadap agama yang dianutnya.

Pembangunan karakter, moral dan religiousitas juga diharapkan dapat mengontrol tindakan seseorang temasuk juga pengontrolan emosi. Kemampuan mengontrol diri tersebut bagian dari moral atau akhlak yang dimiliki oleh seseorang dan menjadi penanda kesiapan dan tanggung-jawab untuk melaksanakan ajaran agama serta menjahui laranganNya. Perilaku agresif lain yang berupa kekerasan fisik, seksual dan emosi, individu atau kelompok yang menyerang satu sama lain, termasuk sebagai suatu perilaku agresif yang perlu perhatian dari seluruh pihak dalam hal ini adalah guru, orang tua dan lingkungan. Agresif berdampak sangat buruk terhadap karakter dan lingkungan sehingga segera membutuhkan solusi yang sangat cepat dan tepat (Nasikhah \& Prihastuti, 2013). 
Penelitian yang dilakukan oleh Annisa (2019) tentang implementasi pendidikan karakter disiplin di sekolah menyimpulkan bahwa untuk mendukung tercapainya keberhasilan nilai karakter disiplin di sekolah ini, dibuat tujuh kebijakan sekolah. Tujuh kebijakan tersebut adalah program pendidikan karakter, menetapkan aturan sekolah dan aturan kelas, melakukan sholat dhuha dan sholat dzuhur berjamaah, membuat pos afektif di setiap kelas, memantau perilaku kedisiplinan siswa di rumah melalui buku catatan kegiatan harian, dan melibatkan orang tua, dan melibatkan komite sekolah. Pelaksanaan kebijakan tersebut perlu dukungan dari seluruh warga sekolah baik kepala sekolah, guru, orang tua, komite sekolah, karyawan, dan siswa.

Penelitian ini menjelaskan hubungan perilaku agresif dengan pola pendidikan kedisiplinan di Lingkungan Pendidikan Al-Ishlah Bobos Cirebon pada Tahun Pelajaran 2018-2019. Pihak lembaga menerapkan beragam kegiatan baik intra kurikuler (masuk kurikulum sekolah) maupun ekstra kurikuler. Kegiatan Ekstrakulikuler Siswa dan Siswi MA Al-Ishlah terdiri dari: OSIS, Pramuka, Paskibra, PKS, PMR, Pasus, Sanggar Seni, Tater, Group Band Musik, Drum Band, Sinpala. grup Shalawat dan Qosidah Modern. Penelitian ini dilakukan untuk mengetahui;

Seberapa besar pengaruh kedisiplinan siswa dengan perilaku agresif siswa yang terjadi di Pendidikan Al-Ishlah? (b) Seberapa besar pengaruh religiositas siswa dengan perilaku agresif siswa yang terjadi di Pendidikan Al-Ishlah? Dan (c) Apakah terdapat relasi antara pendidikan kedisplinan siswa dan religiositas dengan perilaku agresif siswa yang terjadi di
Pendidikan Al-Ishlah Tahun Pelajaran 2018/2019?.

\section{Metode}

Penelitian ini merupakan penelitian kuantitatif untuk menganalisis Relasional Penerapan Pendidikan Kedisplinan dan Religiositas dengan Kecenderungan Perilaku Agresif Siswa di Lingkungan Pendidikan Al-Ishlah Bobos Cirebon Tahun Pelajaran 2018-2019.

A. Teknik Pengumpulan Data dengan menggunakan: Angket, Wawancara,dan Studi Dokumentasi.

Peneliti melakukan penelitian lapangan, yaitu penulis melakukan penelitian langsung di lingkungan Pendidikan Al-Ishlah Bobos Cirebon Tahun Pelajaran 2018-2019. Guna mendapatkan dan mengumpulkan informasi atau datadata, penelitian ini menggunakan desain eksperimen yang bersifat ekspos facto.

Penelitian bertujuan untuk mengumpulkan informasi atau data-data dengan mewawancarai dan membagikan angket pada sebagian kecil yang terpilih berdasarkan sistem random dan mendokumentasikan praktek lapangan yang ada kaitannya dengan penelitian ini.

Sumber data dalam penelitian ini secara umum terbagi atas dua, yaitu: sumber data primer dan sumber data sekunder. Data primer pada penelitian ini terbagi atas tiga komponen, yaitu; place (tempat), actor (pelaku), dan activities (aktivitas).Berkenan dengan place (tempat), merupakan informasi (data) yang dikumpulkan lansung dari sumbernya di lapangan.

B. Analisis Data 
Pada penelitian ini, uji analisis data akan dilakukan mulai dari uji asumsi sampai dengan uji hipotesis. Pengujian analisis ini akan dilakukan dengan menggunakan aplikasi SPSS 16.00.

1. Uji Asumsi

a) Uji Normalitas

Uji normalitas memiliki tujuan untuk melihat data sampel yang telah diambil apakah mengikuti sebaran distribusi normal.Sebaran dapat dilihat dari tabel histogram maupun plot datanya.Data yang dikatakan berdistribusi normal merupakan data yang mengikuti atau berada di sekitar garis normal.Normalitas ini penting untuk membuat generalisasi atas data sampel.

b) Uji Homogenitas

Uji Homogenitas bertujuan untuk sampel yang diteliti memiliki varian yang sama. Jika sampel yang digunakan untuk penelitian tidak memiliki varian yang sama maka uji ANOVA tidak dapat diberikan.

c) Uji Linearitas

Tujuan dari uji linearitas adalah memastikan data sampel sesuai dengan garis linear atau tidak. Linearitas suatu data dapat dilihat dari plot data linearnya.

2. Uji Hipotesis

Pegujian hipotesis menggunakan analisis korelasi dengan aplikasi SPSS versi 16.Analisa ini bertujuan agar peneliti dapat mengetahui ada tidaknya hubungan dan kekuatan hubungan antar varibel secara keseluruhan dan juga peneliti dapat melihat arah hubungan dari kedua variabel yang diteliti. Tahapan pengujian hipotesis dilanjutkan dengan mengajukan kriteria sebagai berikut;

H01 : Tidak ada pengaruh yang negatif antara pendidikan kedisiplinan di sekolah dengan perilaku agresif siswa Pendidikan Al-Ishlah tahun pelajaran 2018/2019.

Ha1 : Terdapat hubungan yang negatif antara pendidikan kedisiplinan di sekolah dengan perilaku agresif siswa Pendidikan Al-Ishlah tahun pelajaran 2018/2019

Dan ;

H02 : Tidak ada pengaruh yang negatif antara tingkat religiositas siswa dengan perilaku agresif siswa Pendidikan Al-Ishlah tahun pelajaran 2018/2019.

Ha2 : Terdapat hubungan yang negatif antara tingkat religiositas siswa dengan perilaku agresif siswa Pendidikan Al-Ishlah tahun pelajaran 2018/2019

Pengambilan keputusan dilakukan dengan tahapan selanjutnya menggunakan kriteria berikut.

Setelah didapat nilai t-hitung dari Analisis Regresi Linier Berganda.

Penarikan Kesimpulan berlaku ketentuan sebagai berikut:

- Jika thitung > ttabel Ho ditolak ( ada hubungan yang signifikan )

- Jika thitung <t-tabel maka Ho diterima ( tidak ada hubungan yang signifikan )

Dengan catatan nilai t-hitung diperoleh dari tabel statistik uji-T membandingkan jumlah sampel penelitian 
$\mathrm{N}$ dan tingkat signifikansi $95 \%$ pada uji 2 sisi (2-tailed).

\section{Hasil dan Pembahasan}

Tahapan pelaksanaan analisis statistik untuk menyelesaikan permasalahan penelitian ini dilakukan setelah melakukan rekapitulasi data respon dari hasil kuesioner yang didistribusikan kepada para siswa.Setelah data direkap, selanjutnya dilakukan pengujian data untuk tiap kelompok variabel (kuesioner). Setelah itu, proses selanjutnya adalah pengujian data variabel penelitian berupa uji normalitas, homogenitas dan linieritas. Pengujian tersebut dijalankan untuk menilai apakah data layak dilanjutkan untuk analisis selanjutnya yaitu analisis regresi linier berganda.

Tujuan analisis regresi linier berganda adalah untuk mengetahui nilai dan signifikansi pengaruh variabel bebas terhadap variabel terikatnya.Untuk menguji hipotesis yang diajukan dapat digunakan uji$\mathrm{T}$ dari hasil analisis regresi linier berganda. Berikut hasil analisis statistik untuk respon data penelitian yang diambil terhadap sejumlah 120 siswa-siswi setingkat Tsanawiyah dan Aliyah di Sekolah AlIshlah Bobos Cirebon

\section{A. Pengaruh Kedisiplinan Siswa dengan Perilaku Agresif Siswa yang Terjadi di Pendidikan Al-Ishlah}

1. Hasil Uji Validitas dan Reliabilitas Butir

Salah satu kriteria data penelitian dapat diterima validitasnya dapat digunakan pengujian hasil validitas item (butir) dengan nilai koefisien korelasi product moment (rxy). Batasan kriteria seleksi aitem dengan menggunakan koefisien korelasi aitem-total adalah $\mathrm{r}_{\mathrm{ix}}>$ 0,30 . Oleh karena itu item yang memiliki koefisiean korelasi aitem-total lebih atau sama dengan 0,30 dianggap memiliki daya diskriminasi yang baik. Sedangkan untuk reliabilitas menggunakan kriteria Alpha Cronbach. Uji reliabilitas dalam penelitian ini menggunakan analisis AlphaCronbach. Alat ukur dianggap reliabel ketika koefisien alpha cronbach menunjukkan angka $>0,60$.

Tabel 1

Uji Validitas dan Reliabilitas Item Kedisiplinan (X1)

\begin{tabular}{|c|c|c|c|}
\hline Pernyataan & $\begin{array}{c}\text { Veliabilitas } \\
\text { Butir } \\
\text { Butir (rxy) }\end{array}$ & $\begin{array}{c}\text { (Cronbach' } \\
\text { s Alpha) }\end{array}$ & Kesimpulan \\
\hline Item 1 & .482 & .794 & Valid / Reliabel \\
Item 2 & .426 & .701 & Valid / Reliabel \\
Item 3 & .422 & .705 & Valid / Reliabel \\
Item 4 & .446 & .784 & Valid / Reliabel \\
Item 5 & .435 & .706 & Valid / Reliabel \\
Item 6 & .483 & .793 & Valid / Reliabel \\
Item 7 & .459 & .790 & Valid / Reliabel \\
Item 8 & .498 & .786 & Valid / Reliabel \\
Item 9 & .442 & .790 & Valid / Reliabel \\
Item 10 & .475 & .788 & Valid / Reliabel \\
Item 11 & .432 & .791 & Valid / Reliabel \\
Item 12 & .496 & .793 & Valid / Reliabel \\
Item 13 & .499 & .786 & Valid / Reliabel \\
Item 14 & .420 & .796 & Valid / Reliabel \\
Item 15 & .417 & .791 & Valid / Reliabel \\
Sumber: & &
\end{tabular}

Sumber: data primer 2019

Hasil analisis pengujian validitas dan reliabilitas item untuk variabel penerapan kedisiplinan siswa menunjukkan bahwa nilai rxy atau validitas item dari masingmasing item lebih besar dari 0,3. Artinya, seluruh item pertanyaan adalah valid. 
Untuk pengujian reliabilitas, nilai Alpha Cronbach masing-masing item menunjukkan lebih besar dari 0,6. Hal bermakna bahwa masing-masing item pernyataan dalam kuesioner penerapan kedisiplinan siswa reliabel.

\section{Hasil Analisis Deskriptif}

Distribusi responden menurut demografi siswa-siswi dapat dilihat dari hasil analisis deskriptif. Peneliti sajikan tabel hasil analisis deskriptif tingkat pendidikan kedisiplinan

Tabel 2

Hasil Analisis Deskriptif Tingkat Pendidikan Kedisiplinan

\begin{tabular}{|c|c|c|}
\hline Kelompok & Jumlah (siswa) & Persentase (\%) \\
\hline Sangat Tinggi & 14 & 11.7 \\
Tinggi & 106 & 88.3 \\
Cukup & 0 & 0 \\
Rendah & 0 & 0 \\
Sangat Rendah & 0 & 0 \\
\hline Total & 120 & 100 \\
\hline
\end{tabular}

Sumber: data primer 2019

Tingkat penerapan pendidikan kedisiplinan di sekolah Al-Ishlah Bobos Cirebon menurut para responden siswa tingkat Tsanawiyah dan Aliyah memiliki kategori tinggi sebanyak 106 anak (86,3\%) dan sangat tinggi 14 anak (11,7\%). Hal ini menunjukkan penerapan kedisiplinan sangat sering dijalankan oleh sekolah sesuai dengan tanggapan para siswa saat menjadi responden penelitian.

3. Analisis Relasional Pendidikan Kedisiplinan Terhadap Perilaku Agresif

Pendidikan Al-Ishlah memiliki kultur lingkungan yang beragam. Kultur Lingkungan Pendidikan Al-Ishlah terdiri dari berbagai macam organisasi masa Islam dan juga berada di lingkungan industri penambangan dan kerajinan.Lingkungan tersebut membawa dampak pertumbuhan dan perkembangan masa remaja anak, tidak terkecuali siswa di lembaga pendidikan di bawah naugan Yayasan Al-Ishlah.

Perilaku Agresif masa remaja menjadi permasalahan, terutama pada masa pendidikan di sekolah menengah. Perilaku-perilaku anak yang menunjukkan agresivitas terkadang akan muncul ketika anak menghadapi masalah dan tidak dapat mengendalikan dirinya dengan baik dalam berinteraksi dengan lingkungannya. Hal tersebut terjadi karena adanya beberapa faktor yang mempengaruhi. Faktor tersebut dapat berupa tingkat kedisiplinan dan religiositas. Penelitian yang dilakukan saat ini tercetus karena melihat beberapa perkembangan pokok permasalahan di lapangan terutama di Sekolah Al-Ishlah, di antaranya adalah; pendidikan kedisiplinan di lembaga pendidikan AlIshlah sudah diterapkan, bahkan adanya kegiatan ekstra/intra sekolah untuk menunjang pendidikan kedisiplinan siswa. Namun, di sisi lain masih adanya perilaku agresif siswa di lingkungan pendidikan Al-Ishlah; adanya siswa yang melakukan pelanggaran disiplin atau aturan sekolah meskipun guru dan pihak sekolah sudah melakukan penanaman moral melalui pendidikan religi di lingkungan sekolah.

Program Unggulan Madrasah di Lingkungan Al-Ishlah Bobos untuk menjawab penanaman kedisiplinan pada siswa sudah dilakukan di antaranya adalah Shalat Dhuha, Praktek Ibadah: 
Wudhu, Shalat Wajib, Shalat Sunnah Rawatib, tahlilan, dan lain-lain, Praktek Kultum siswa setiap pagi dan praktek Tadarus Al-Qur'an Setiap Awal Pelajaran. Dimungkinkan adanya telaah lebih mendalam tentang perilaku dan tingkat kedisiplinan para siswa di sekolah Al-Ishlah Bobos Cirebon.

\section{B. Pengaruh Religiositas Siswa dengan Perilaku Agresif Siswa yang Terjadi di Pendidikan Al-Ishlah}

1. Hasil Uji Validitas dan Reliabilitas Butir

Peneliti menyajikan Hasil Uji Validitas dan Reabilitas dalam Tabel 3 dibawah ini:

\section{Tabel 3}

Uji Validitas dan Reliabilitas Item Religiositas Siswa (X2)

\begin{tabular}{|c|c|c|c|}
\hline Pernyataan & $\begin{array}{c}\text { Validit } \\
\text { as } \\
\text { Butir } \\
\text { (rxy) }\end{array}$ & $\begin{array}{c}\text { Reliabilitas } \\
\text { Butir } \\
\text { (Cronbach's } \\
\text { Alpha) }\end{array}$ & Kesimpulan \\
\hline Item 1 & .454 & .700 & Valid / Reliabel \\
Item 2 & .418 & .712 & Valid / Reliabel \\
Item 3 & .404 & .715 & Valid / Reliabel \\
Item 4 & .417 & .798 & Valid / Reliabel \\
Item 5 & .443 & .717 & Valid / Reliabel \\
Item 6 & .460 & .706 & Valid / Reliabel \\
Item 7 & .438 & .702 & Valid / Reliabel \\
Item 8 & .411 & .797 & Valid / Reliabel \\
Item 9 & .448 & .701 & Valid / Reliabel \\
Item 10 & .473 & .700 & Valid / Reliabel \\
Item 11 & .485 & .705 & Valid / Reliabel \\
Item 12 & .402 & .704 & Valid / Reliabel \\
Item 13 & .415 & .797 & Valid / Reliabel \\
Item 15 & .424 & .703 & .700 \\
Valid / Reliabel \\
Valid / Reliabel
\end{tabular}

Sumber: data primer 2019
Hasil analisis pengujian validitas dan reliabilitas item untuk variabel religiositas siswa menunjukkan bahwa nilai rxy atau validitas item dari masing-masing item lebih besar dari 0,3. Dapat diartikan bahwa seluruh item pertanyaan valid. Untuk pengujian reliabilitas, nilai Alpha Cronbach masing-masing item menunjukkan lebih besar dari 0,6. Artinya bahwa masing-masing item pernyataan dalam kuesioner religiositas siswa reliabel.

\section{Hasil Analisis Deskriptif}

Distribusi responden menurut demografi siswa-siswi dapat dilihat dari hasil analisis deskriptif. Peneliti sajikan tabel hasil analisis deskriptif tingkat Religius siswa dibawah ini:

Tabel 4

Hasil Analisis Deskriptif Tingkat Religiositas Siswa

\begin{tabular}{|c|c|c|}
\hline Kelompok & $\begin{array}{l}\text { Jumlah } \\
\text { (siswa) }\end{array}$ & Persentase $(\%)$ \\
\hline Sangat Tinggi & 18 & 15.0 \\
\hline Tinggi & 102 & 85.0 \\
\hline Cukup & 0 & 0 \\
\hline Rendah & 0 & 0 \\
\hline Sangat Rendah & 0 & 0 \\
\hline Total & 120 & 100 \\
\hline
\end{tabular}

Tingkat religiositas siswa di sekolah Al-Ishlah Bobos Cirebon menurut para responden siswa tingkat Tsanawiyah dan Aliyah memiliki kategori tinggi sebanyak 
102 anak (85\%) dan sangat tinggi 18 anak (15\%). Hal ini menunjukkan tingkat religiositas siswa di sekolah sangat baik sesuai dengan tanggapan para siswa saat menjadi responden penelitian.

3. Analisis Relasional Religiositas Siswa Terhadap Perilaku Agresif

Hasil yang diperoleh dari penelitian ini adalah hubungan negatif yang cukup Tingkat religiositas siswa di sekolah AlIshlah Bobos Cirebon menurut para responden siswa tingkat SMP dan Aliyah memiliki kategori tinggi sebanyak 102 anak $(85 \%)$ dan sangat tinggi 18 anak (15\%). Hal ini menunjukkan tingkat religiositas siswa di sekolah sangat baik.

Adapun kriteria-kriteria yang dimasukkan penilaian dalam kuesioner terdapat kelima dimensi religiositas yang dapat mengukur mentalitas dan perilaku religi, yaitu dimensi diantaranya; dimensi keyakinan (ideologis), dimensi praktik agama (ritualistik), dimensi penghayatan (eksperienial), dimensi pengetahuan agama (intelektual), dimensi pengalaman dan konsekuensi. Unsurunsur tersebut banyak terkait dengan program-program pendidikan religius yang menjadi ciri khas Sekolah di AlIshlas Bobos Cirebon. Program yang menjadi ciri khas memiliki materi religiositas yang pantas dipertimbangkn; Praktek Manasik Haji pada hari Raya 'Idul Adha lengkap dengan pemotongan hewan Qurban; Membentuk sikap dan kepribadian serta budaya Islami; dan program Siap terjun ke masyarakat dengan bekal ilmu yang telah dimiliki.

Hasil penelitian menyimpulkan bahwa sikap religiositas terbukti efektif mengurangi perilaku agresif dari kategori tinggi (pre test) menjadi kategori rendah (post-test) setelah perlakuan. Pihak sekolah Al-Ikhlas Bobos Cirebon sudah berusaha mengurangi agresif siswa program pendidikan yang menjadi ciri khas dapat mengurangi kecenderungan perilaku agresif tersebut. Program pendidikan di Lembaga Al-Ishlah memiliki ciri khas. Adapun ciri khas pelaksanaan program pendidikan di Lembaga Al-Ishlah di antaranya adalah sebagai berikut; (1) Berdo'a dan membaca Intisab bersama di halaman sebelum masuk kelas (2) Tadarus AlQur'an setiap pagi hari sebelum mulai proses pembelajaran (3) Shalat Dzuhur berjama'ah seluruh siswa dan karyawan (4) Pembinaan Shalat Dhuha bersama (5) Bakti Sosial bulan Ramadhan ke tiap-tiap Musholla sekitar dengan melakukan kebersihan dan tebar Al-Qur'an dan (9) Berani bersaing dengan sekolah lain yang sederajat untuk melanjutkan ke sekolah favorit lebih tinggi.

\section{Relasi antara Pendidikan Kedisplinan Siswa dan Religiositas dengan Perilaku Agresif Siswa yang Terjadi di Pendidikan Al-Ishlah Tahun Pelajaran 2018/2019}

1. Hasil Uji Validitas dan Reliabilitas Butir

Peneliti menyajikan Hasil Uji Validitas dan Reabilitas Perilaku Agresif siswa dalam Tabel 5 dibawah ini: 
Tabel 5

Uji Validitas dan Reliabilitas Item Perilaku Agresif (Y)

\begin{tabular}{|c|c|c|c|}
\hline Pernyataan & $\begin{array}{c}\text { Validitas } \\
\text { Butir } \\
\text { (rxy) }\end{array}$ & $\begin{array}{l}\text { Reliabilita } \\
\text { s Butir } \\
\text { (Cronbach's } \\
\text { Alpha) }\end{array}$ & Kesimpulan \\
\hline Item 1 & .439 & .714 & $\begin{array}{c}\text { Valid / } \\
\text { Reliabel }\end{array}$ \\
\hline Item 2 & .468 & .727 & $\begin{array}{c}\text { Valid / } \\
\text { Reliabel }\end{array}$ \\
\hline Item 3 & .422 & .727 & $\begin{array}{l}\text { Valid / } \\
\text { Reliabel }\end{array}$ \\
\hline Item 4 & .426 & .709 & $\begin{array}{c}\text { Valid / } \\
\text { Reliabel }\end{array}$ \\
\hline Item 5 & .433 & .727 & $\begin{array}{c}\text { Valid / } \\
\text { Reliabel }\end{array}$ \\
\hline Item 6 & .490 & .716 & $\begin{array}{c}\text { Valid / } \\
\text { Reliabel }\end{array}$ \\
\hline Item 7 & .497 & .716 & $\begin{array}{c}\text { Valid / } \\
\text { Reliabel }\end{array}$ \\
\hline Item 8 & .402 & .710 & $\begin{array}{c}\text { Valid / } \\
\text { Reliabel }\end{array}$ \\
\hline Item 9 & .476 & .712 & $\begin{array}{c}\text { Valid / } \\
\text { Reliabel }\end{array}$ \\
\hline Item 10 & .486 & .711 & $\begin{array}{c}\text { Valid / } \\
\text { Reliabel }\end{array}$ \\
\hline Item 11 & .424 & .715 & $\begin{array}{c}\text { Valid / } \\
\text { Reliabel }\end{array}$ \\
\hline Item 12 & .425 & .715 & $\begin{array}{c}\text { Valid / } \\
\text { Reliabel }\end{array}$ \\
\hline Item 13 & .427 & .709 & $\begin{array}{c}\text { Valid / } \\
\text { Reliabel }\end{array}$ \\
\hline Item 14 & .430 & .714 & $\begin{array}{c}\text { Valid / } \\
\text { Reliabel }\end{array}$ \\
\hline Item 15 & .461 & .712 & $\begin{array}{c}\text { Valid / } \\
\text { Reliabel }\end{array}$ \\
\hline
\end{tabular}

Hasil analisis pengujian validitas dan reliabilitas item untuk variabel perilaku agresif siswa menunjukkan bahwa nilai rxy atau validitas item dari masing-masing item lebih besar dari 0,3. Dapat diartikan bahwa seluruh item pertanyaan valid. Untuk pengujian reliabilitas, nilai Alpha Cronbach masing-masing item menunjukkan lebih besar dari 0,6. Artinya bahwa masing-masing item pernyataan dalam kuesioner perilaku agresif siswa reliabel.

2. Hasil Uji Normalitas, Homogenitas dan Linieritas

Pengujian Normalitas, Homogenitas dan Linieritas dilakukan sebagai prasyarat bahwa data penelitian dapat dipakai untuk analisis statistik selanjutnya yaitu analisis regresi linier berganda, jika data penelitian dinyatakan sudah memenuhi normalitas, homogenitas dan linieritas sebagai sebuah data analisis parametrik. Sebagaimana dipersyaratkan dalam analisis parametrik, bahwa data harus terdistribusi normal, homogen dan memiliki keterkaitan linieritas agar dapat dilakukan analisis statistik regresi linier. 
Tabel 6

Hasil Uji Normalitas, Homogenitas dan Linieritas

\begin{tabular}{|c|c|c|c|}
\hline Hasil Uji & $\begin{array}{c}\text { Penerapan } \\
\text { Pendidikan } \\
\text { Kedisiplinan } \\
\text { (X1) }\end{array}$ & $\begin{array}{l}\text { Religiusitas } \\
\text { Siswa (X2) }\end{array}$ & $\begin{array}{c}\text { Perilaku Agresif } \\
\text { Siswa (Y) }\end{array}$ \\
\hline \multicolumn{4}{|l|}{ UII NORMALITAS } \\
\hline Kolmogorov-Smimov Z & 1,084 & 0,917 & 0,902 \\
\hline $\begin{array}{l}\text { Asymp. Sig. (2-tailed) } \\
\text { UJI HOMOGENITAS }\end{array}$ & 0,191 & 0,369 & 0,391 \\
\hline Levene Test & 0,834 & 1,020 & \\
\hline Sig F & 0,432 & 0,120 & \\
\hline \multicolumn{4}{|l|}{ UJI LINIERITAS } \\
\hline$F$ tes & 0,819 & 0,743 & \\
\hline Sig F & 0,724 & 0,823 & \\
\hline
\end{tabular}

Sumber: data primer 2019

Hasil pengujian normalitas, homogenitas dan linieritas menunjukkan bahwa data penelitian dari masing-masing variabel yaitu penerapan kedisiplinan siswa (X1), religiositas siswa (X2) dan perilaku agresif siswa (Y) memenuhi kriteria batas normalitas, homogenitas dan linieritas. Dapat dilihat bahwa nilai sig. F masing-masing pengujian untuk tiap variabel lebih besar dari 0,05 (sig. $\mathrm{F}>0,05)$. Dapat diartikan bahwa variabel penerapan kedisiplinan siswa (X1), religiositas siswa $(\mathrm{X} 2)$ dan perilaku agresif siswa (Y) memenuhi data terdistribusi normal, data homogen (varians sama) dan memilki keterkaitan linieritas antara variabel bebas (penerapan kedisiplinan siswa (X1), religiositas siswa (X2)) dan variabel terikat (perilaku agresif siswa (Y).

\section{Hasil Analisis Deskriptif}

Distribusi responden menurut demografi siswa-siswi dapat dilihat dari hasil analisis deskriptif.Analisis frekuensi dilakukan untuk melihat jumlah siswasiswi sebagai responden penelitian menurut kelas, umur dan jenis kelamin.Distribusi responden yang merata untuk masing-masing kategori kelompok kelas, umur dan jenis kelamin menunjukkan bahwa data penelitian dapat mewakili dari seluruh sampel dan populasi subjek penelitian.

\section{Tabel 7}

Hasil Analisis Deskriptif Jumlah Responden Menurut Kelas

\begin{tabular}{|c|c|c|}
\hline Kelompok & Jumlah(siswa) & $\begin{array}{c}\text { Persentase } \\
(\%)\end{array}$ \\
\hline 8 & 30 & 25 \\
\hline 9 & 30 & 25 \\
\hline 10 & 30 & 25 \\
\hline 11 & 30 & 25 \\
\hline Total & 120 & 100 \\
\hline
\end{tabular}

Menurut kelompok kelas dari para siswa, dapat dilihat bahwa pengambilan data tersebar merata dari kelas 8 sampai kelas 11.Masing-masing kelas diambil sampel sejumlah 30 siswa. Kelompok siswa pada kelas 8 sampai kelas 11 menunjukkan kelompok siswa pada usia remaja dan pertumbuhan. Kelompok usia tersebut sangat sensitif terhadap perubahan lingkungan dan memiliki rasa ingin tahu yangtinggi terhadap perubahan lingkungan. 
Tabel 8

Hasil Analisis Deskriptif Jumlah Responden Menurut Umur

\begin{tabular}{|c|c|c|}
\hline Kelompok & Jumlah (siswa) & $\begin{array}{c}\text { Persentase } \\
(\%)\end{array}$ \\
\hline 14 & 22 & 18,3 \\
15 & 34 & 28,3 \\
16 & 34 & 28,3 \\
17 & 29 & 24,2 \\
18 & 1 & 0,8 \\
\hline Total & 120 & 100 \\
\hline
\end{tabular}

Sumber: data primer 2019

Berdasarkan kelompok umur, dapat diketahui bahwa kelompok usia 14 sampai usia 17 tahun sebagai kelompok usia yang dominan menjadi partisipan dalam penelitian ini. Kelompok usia 14 sampai 18 tahun sebagai kelompok usia remaja yang layak mewakili untuk penelitian ini. Jumlah data siswa tersebar merata untuk kelompok usia antara 14 tahun sampai 17 tahun sedangkan kelompok usia 18 tahun hanya ditemukan 1 siswa.

Tabel 9

Hasil Analisis Deskriptif Jumlah Responden Menurut Jenis Kelamin

\begin{tabular}{|c|c|c|}
\hline Kelompok & Jumlah(siswa) & $\begin{array}{c}\text { Persentase } \\
(\%)\end{array}$ \\
\hline Laki-laki & 68 & 56,7 \\
Perempuan & 52 & 43,3 \\
\hline
\end{tabular}

\begin{tabular}{|c|c|c|}
\hline Kelompok & Jumlah(siswa) & $\begin{array}{c}\text { Persentase } \\
(\%)\end{array}$ \\
\hline Laki-laki & 68 & 56,7 \\
\hline Total & 120 & 100 \\
\hline \multicolumn{2}{|c|}{ Sumber: data primer 2019 }
\end{tabular}

Sebaran data penelitian menurut kelompok jenis kelamin menunjukkan bahwa data penelitian tersebar merata menurut kelompok jenis kelamin.Tidak terdapat perbedaan besar untuk jumlah siswa laki-laki dengan perempuan. Ditemukan bahwa siswa laki-laki berjumlah 68 anak dan siswa perempuan berjumlah 52 anak.Menurut populasi siswa yang terdaftar menjadi santri di sekolah Al-Ishlah, jumlah siswa laki-laki lebih banyak dari siswa perempuan.Dengan demikian data penelitian dapat mewakili dari seluruh populasi.

\section{Tabel 10}

Hasil Analisis Deskriptif Tingkat Perilaku Agresif Siswa

\begin{tabular}{|c|c|c|}
\hline Kelompok & Jumlah (siswa) & $\begin{array}{c}\text { Persentase } \\
(\%)\end{array}$ \\
\hline Sangat Tinggi & 0 & 0 \\
\hline Tinggi & 0 & 0 \\
\hline Cukup & 0 & 0 \\
\hline Rendah & 16 & 13.3 \\
\hline Sangat Rendah & 104 & 86.7 \\
\hline Total & 120 & 100 \\
\hline
\end{tabular}

Tingkat perilaku agresif siswa di sekolah Al-Ishlah Bobos Cirebon menurut para responden siswa tingkat Tsanawiyah dan Aliyah memiliki kategori rendah 
sebanyak 16 anak $(13,3 \%)$ dan sangat rendah 104 anak (86,7\%). Hal ini menunjukkan tingkat perilaku agresif siswa di sekolah sangat rendah sesuai dengan tanggapan para siswa saat menjadi responden penelitian.

\section{Hasil Pengujian Hipotesis}

Untuk menguji hipotesis penelitian, dilakukan pengujian menggunakan ujit.Uji-t. hal tersebut bisa diperoleh dari hasil analisis regresi linier berganda untuk penelitian ini. Hasil analisis regresi linier berganda dapat diperoleh besaran pengaruh dan tingkat signifikansi dampak variabel bebas (penerapan kedisiplinan siswa (X1) dan religiusits siswa (X2)) terhadap variabel terikatnya (perilaku agresif siswa (Y)).

Kriteria ada atau tidak ada pengaruh variabel penerapan kedisiplinan siswa (X1) dan religiusits siswa (X2) terhadap variabel perilaku agresif siswa $(\mathrm{Y})$ dilihat pada nilai t-tes. Jika nilai t-tes lebih besar dari nilai ttabel, maka dapat disimpulkan bahwa variabel kedisiplinan siswa (X1) atau religiusits siswa (X2) memiliki pengaruh signifikan terhadap variabel perilaku agresif siswa (Y) secara independen.Jika nilai F-tes lebih besar dari nilai F-tabel, maka dapat disimpulkan bahwavariabel kedisiplinan siswa (X1) atau religiusits siswa (X2) memiliki pengaruh signifikan terhadap variabel perilaku agresif siswa (Y) secara simultan. Besaran koefisien regresi menunjukkan apakah variabel bebas(penerapan kedisiplinan siswa (X1) dan religiusits siswa (X2) memberikan pengaruh positif atau negatif terhadap variabel kecenderungan perilaku agresif siswa.

\section{Tabel11}

Hasil Analisis Regresi Tabel Anova

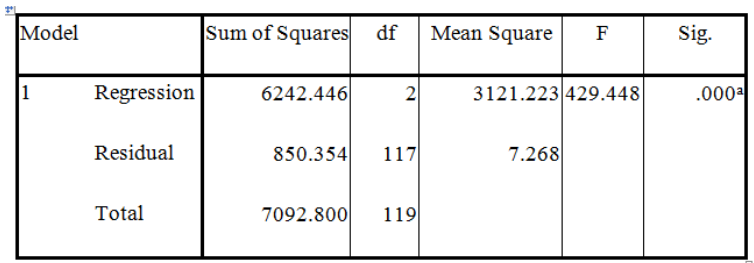

Sumber: data primer 2019

Tabel Anova hasil analisis regresi dapat digunakan untuk melakukan pengujian hipotesis penelitian.Untuk penelitian ini, dapat disimpulkan bahwavariabel kedisiplinan siswa (X1) dan religiusits siswa (X2) memiliki pengaruh signifikan terhadap variabel perilaku agresif siswa $(Y)$ secara simultan.jika nilai F-tes lebih besar dari nilai F-tabel.

Tabel 12

Hasil Analisis Regresi

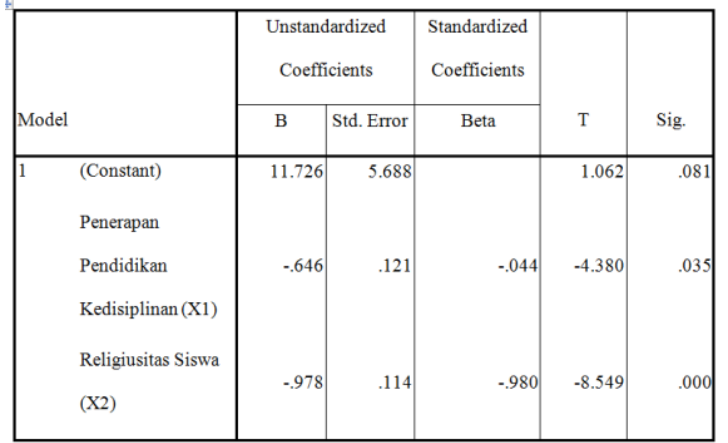

a. Dependent Variable: Perilaku Agresif Siswa (Y)

Tabel Anova di atas dapat digunakan untuk menentukan pengujian hipotesis dalam penelitian ini.Penyimpulan hipotesis ditentukan dengan melihat besaran pada kolom t, di mana menyatakan sebagai t-tes dalam penelitian.Jika nilai t-tes lebih besar dari nilai t-tabel, maka dapat disimpulkan bahwa variabel kedisiplinan siswa (X1) 
atau religiusits siswa (X2) memiliki pengaruh signifikan terhadap variabel perilaku agresif siswa (Y) secara independen.

Tabel 13

Ringkasan Hasil Pengujian Hipotesis (uji-T dan uji-F)

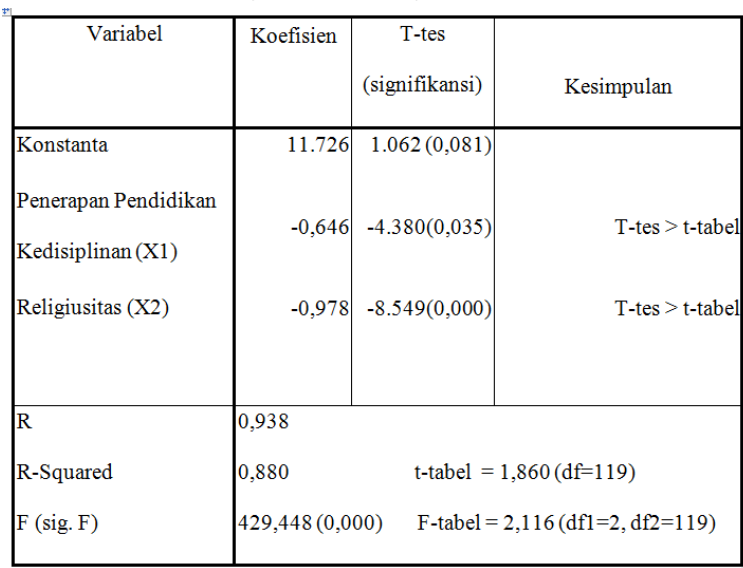

Sumber: data primer 2019

Tabel Anova dan tabel koefisien di atas dapat dirangkum dalam sebuah tabel hasil pengujian hipotesis dengan rincian sebagai berikut. Hasil analisis regresi menunjukkan bahwa nilai t-tes variabel penerapan pendidikan kedisiplinan sebesar 4,380 lebih besar dari t-tabel $(1,860)$ dan nilai t-tes variabel religiositas siswa sebesar 8,549 lebih besar dari t-tabel $(1,860)$. Artinya bahwa variabel penerapan pendidikan kedisiplinan dan religiositas siswa memiliki pengaruh signifikan terhadap kecenderungan perilaku agresif siswa.

Nilai koefisien regresi untuk variabel penerapan pendidikan kedisiplinan sebesar -0,646 dan nilai koefisien regresi untuk variabel religiositas siswa sebesar -0978. Artinya bahwa variabel penerapan pendidikan kedisiplinan dan religiositas siswa memiliki pengaruh negatif terhadap kecenderungan perilaku agresif siswa. Hal ini ditunjukkan dengan nilai koefisien regresi bertanda negatif.

Untuk hasil analisis regresi linier berganda untuk penelitian ini dapat dituliskan pada rumusan berikut ini;

Perilaku agresif siswa $=11,726-0,646$ (penerapan pendidikan kedisiplinan) 0,978 (religiositas siswa)

Dengan mempertimbangkan hasil penyimpulan di atas, maka pengujian hipotesis penelitian dapat teruji menggunakan t-tes dan besaran koefisien persamaan regresi. Sebagaimana tahapan pengujian, tahapan pengujian hipotesis dilakukan dengan mengajukan kriteria sebagai berikut;

Ho1 : Tidak ada pengaruh yang negatif antara pendidikan kedisiplinan di sekolah dengan perilaku agresif siswa Pendidikan Al-Ishlah tahun pelajaran 2018/2019.

Ha1 : Terdapat pengaruh yang negatif antara pendidikan kedisiplinan di sekolah dengan perilaku agresif siswa Pendidikan Al-Ishlah tahun pelajaran 2018/2019

Pengambilan keputusan dilakukan dengan tahapan selanjutnya menggunakan kriteria jika t-tes> t-tabel Ho ditolak ( ada hubungan yang signifikan ) dan koefisien regresi bertanda negatif yang artinya adanya pengaruh negatif. Penarikan Kesimpulan berlaku ketentuan di atas hipotesis penelitian yang berbunyi "Adanya pengaruh negatif signifikan antara penerapan pendidikan kedisiplinan di sekolah dengan perilaku agresif siswa Sekolah Al-Ishlah tahun pelajaran 2018/2019 dierima. 
Untuk hipotesis kedua tentang hubungan religiositas siswa terhadap kecenderungan perilaku agresif siswa dapat ditentukan sebagai berikut.

$\mathrm{H}_{02}$ : Tidak ada pengaruh yang negatif antara tingkat religiositas siswa dengan perilaku agresif siswa Pendidikan Al-Ishlah tahun pelajaran 2018/2019.

$\mathrm{H}_{\mathrm{a} 2}$ : Terdapat pengaruh yang negatif antara tingkat religiositas siswa dengan perilaku agresif siswa Pendidikan Al-Ishlah tahun pelajaran 2018/2019

Pengambilan keputusan dilakukan dengan tahapan selanjutnya menggunakan kriteria jika t-tes> t-tabel Ho ditolak ( ada hubungan yang signifikan ) dan koefisien regresi bertanda negatif yang artinya adanya pengaruh negatif. Penarikan Kesimpulan berlaku ketentuan di atas hipotesis penelitian yang berbunyi "Adanya pengaruh negatif signifikan antara religiositas siswa di sekolah dengan perilaku agresif siswa Sekolah Al-Ishlah tahun pelajaran 2018/2019 dierima.

\begin{tabular}{rrr}
\multicolumn{2}{c}{ Pengujian } & secara \\
keterkaitan penerapan & pendidikan
\end{tabular} kedisiplinan siswa dan religiositas siswa terhadap kecenderungan agresif siswa dapat diuji menggunakan uji-F. Hasil pengujian menunjukkan bahwa terdapat pengaruh sangat kuat (nilai $\mathrm{R}$ korelasi berganda sebesar 0,938) signifikan (sig.F< 0,05) penerapan pendidikan kedisiplinan siswa dan religiositas siswa terhadap kecenderungan perilaku agresif siswa secara simultan.

\section{KESIMPULAN}

Berdasarkan hasil analisis dan pembahasan di atas maka dapat disimpulkan keterkaitan antara variabel penelitian selama periode penelitian 2018/2019 sebagai berikut;

1) Tingkat penerapan pendidikan kedisiplinan di sekolah Al-Ishlah Bobos Cirebon menurut para responden siswa tingkat Tsanawiyah dan Aliyah memiliki kategori tinggi sebanyak 106 anak (86,3\%) dan sangat tinggi 14 anak $(11,7 \%)$. Hal ini menunjukkan penerapan kedisiplinan sangat sering dijalankan oleh sekolah

2) Tingkat religiositas siswa di sekolah Al-Ishlah Bobos Cirebon menurut para responden siswa tingkat Tsanawiyah dan Aliyah memiliki kategori tinggi sebanyak 102 anak $(85 \%)$ dan sangat tinggi 18 anak (15\%). Hal ini menunjukkan tingkat religiositas siswa di sekolah sangat baik

3) Tingkat perilaku agresif siswa di sekolah Al-Ishlah Bobos Cirebon menurut para responden siswa tingkat Tsanawiyah dan Aliyah memiliki kategori rendah sebanyak 16 anak $(13,3 \%)$ dan sangat rendah 104 anak (86,7\%). Hal ini menunjukkan tingkat perilaku agresif siswa di sekolah sangat rendah

4) Terdapat pengaruh negatif signifikan penerapan pendidikan kedisiplinan siswa terhadap kecenderungan agresif siswa di Sekolah Al-Ishlah Bobos Cirebon. Artinya setiap terjadi peningkatan penerapan pendidikan kedisiplinan siswa maka 
tingkat kecenderungan agresif para siswa di Sekolah Al-Ishlah Bobos Cirebon akan menurun. Selain itu, terdapat juga pengaruh negatif signifikan religiositas siswa terhadap kecenderungan agresif siswa di Sekolah Al-Ishlah Bobos Cirebon. Artinya setiap terjadi peningkatan religiositas siswa maka tingkat kecenderungan agresif para siswa di Sekolah Al-Ishlah Bobos Cirebon akan menurun.

\section{DAFTAR PUSTAKA}

Annisa, F. (2019). Penanaman nilai-nilai pendidikan karakter disiplin pada siswa Sekolah Dasar. Jurnal Perspektif Pendidikan dan Keguruan, 10 (1), 1-7. doi:https://doi.org/10.25299/perspektif. 2019.vol10(1).3102

Azizah, N. (2016). Perilaku Moral dan Religiusitas Siswa Berlatar Belakang Pendidikan Umum dan agama. Jurnal Psikologi, 33(2), 57-76. https://doi.org/10.22146/JPSI.7078

Hadianti, S. (2017). Pengaruh Pelaksanaan Tata Tertib Sekolah terhadap Kedisiplinan Belajar Siswa (Penelitian Deskriftif Analisis di SDN Sukakarya II Kecamatan samarang Kabupaten Garut). Jurnal Pendidikan UNIGA, 2(1), 14-28.

Jumarudin, Gafur, A., \& Suardiman, S. P. (2014). Pengembangan Model Pembelajaran Humanis Religius dalam Pendidikan Karakter di Sekolah Dasar. Jurnal Pembangunan Pendidikan: Fondasi Dan Aplikasi, 2(2), 26-52. https://doi.org/10.21831/jppfa.v2i2.262 3

Nasikhah, D., \& Prihastuti. (2013). Hubungan antara Tingkat Religiusitas dengan Perilaku Kenakalan Remaja pada Masa Remaja Awal. Jurnal
Psikologi Pendidikan Dan

Perkembangan, 2(2), 37-58.

Ramdhani, M. A. (2014). Lingkungan Pendidikan dalam Implementasi Pendidikan Karakter. Jurnal Pendidikan Universitas Garut, 8(1), 45-67.

https://doi.org/10.1177/0022185684026 00108

Satria, R. A., Nurdin, A. E., \& Bachtiar, H. (2015). Hubungan Kecanduan Bermain Video Games Kekerasan dengan Perilaku Agresif pada Murid Laki-laki Kelas IV dan V di SD Negeri 02 Cupak Tangah Pauh Kota Padang. Jurnal Kesehatan Andalas, 4(1), 27-43.

Shofwatal Qolbiyyah. (2017). Kenakalan Remaja (Analisis Tentang Faktor Penyebab dan Solusinya dalam Perspektif Pendidikan Agama Islam). Sumbula: Jurnal Studi Keagamaan, Sosial Dan Budaya, 2(1), 36-49.

Yahya, \& Megalia. (2016). Pengaruh Konseling Cognitif Behavior Therapy (CBT) dengan Teknik Self Control untuk Mengurangi Perilaku Agresif Peserta Didik Kelas VIII di SMPN 9 Bandar Lampung Tahun Pelajaran 2016/2017. KONSELI: Jurnal Bimbingan Dan Konseling (E-Journal), 3(2), 38-55. 